\title{
Work safety applied in the rural environment: a review
}

\author{
Segurança do trabalho aplicada no meio rural: uma revisão \\ Seguridad laboral aplicada en zonas rurales: una revisión
}

Received: 09/02/2021 | Reviewed: 09/09/2021 | Accept: 09/12/2021 | Published: 09/14/2021

Eric Valero Carvalho da Silva

ORCID: https://orcid.org/0000-0003-0385-7619

Universidade Estadual do Oeste do Paraná, Brazil

E-mail: evcdasilva@gmail.com

Filipe Pereira Lopes

ORCID: https://orcid.org/0000-0003-1582-5753

Universidade Tecnológica Federal do Paraná, Brazil

E-mail: filipelopes@alunos.utfpr.edu.br

Jair Antonio Cruz Siqueira

ORCID: https://orcid.org/0000-0002-8140-444X

Universidade Estadual do Oeste do Paraná, Brazil

E-mail: jair.siqueira@unioeste.br

Luciene Kazue Tokura

ORCID: https://orcid.org/0000-0001-9758-0141

Universidade Estadual do Oeste do Paraná, Brazil

E-mail: lucienetokura@gmail.com

\begin{abstract}
This paper aims to present the difficulties encountered in complying with Regulatory Standard No 31 - Occupational Health and Safety in Agriculture, Livestock, Forestry, Forestry and Aquaculture, in rural areas. The research was carried out through consultations in several scientific articles and was justified by the need to make field workers aware of the risks to which they are exposed, in the exercise of their activity. Through several studies that supported this work, it was possible to verify that the use of NR 31 is flawed, even with the scope and detail provided in its text. In the study it was found that, the rural work environment is worrying, due to the numerous risks that are present in the exercise of their activities and the disregard for non-compliance with NR-31. It is essential that government authorities, in addition to inspecting the faithful compliance with the standard, must carry out a work of awareness of workers and employers, aiming to provide an improvement in working conditions in the rural environment. The prioritization that should be given to awareness, education, training, and adequacy of working conditions becomes relevant, as a measure to prevent accidents and diseases in the agricultural sector.
\end{abstract}

Keywords: Work safety; Countryside; NR-31.

\section{Resumo}

$\mathrm{O}$ presente trabalho tem por finalidade apresentar as dificuldades encontradas no cumprimento da Norma Regulamentadora $\mathrm{N}^{\circ} 31$ - Segurança e Saúde no Trabalho na Agricultura, Pecuária, Silvicultura, Exploração Florestal e Aquicultura, no meio rural. A pesquisa foi realizada por meio de consultas em diversos artigos científicos e se justificou devido à necessidade de conscientizar o trabalhador do campo sobre os riscos a que ele é exposto, no exercício de sua atividade. Por meio de vários estudos que embasaram este trabalho foi possível constatar que o emprego da NR-31 tem falhas, mesmo com a abrangência e detalhamento previstos em seu texto. No estudo constatou-se que, o ambiente de trabalho rural é preocupante, devido aos inúmeros riscos que se apresentam no exercício de suas atividades e ao desrespeito pelo não cumprimento da NR-31. É imprescindível que as autoridades governamentais, além de fiscalizar o fiel cumprimento da norma, realizem um trabalho de conscientização dos trabalhadores e empregadores, visando proporcionar a melhoria das condições de trabalho no meio rural. Torna-se relevante a priorização que deve ser dada à conscientização, educação, treinamento e adequação das condições de trabalho, como medida de prevenção de acidentes e doenças no setor agrícola.

Palavras-chave: Segurança do trabalho; Meio rural; NR-31.

\section{Resumen}

Este trabajo tiene como objetivo presentar las dificultades encontradas en el cumplimiento de la Norma Reglamentaria No. 31 - Seguridad y Salud en el Trabajo en la Agricultura, Ganadería, Silvicultura, Silvicultura y Acuicultura, en áreas rurales. La investigación se realizó a través de consultas en varios artículos científicos y se justificó por la necesidad de concienciar a los trabajadores de campo de los riesgos a los que están expuestos, en el ejercicio de su actividad. A través de varios estudios que respaldaron este trabajo, se pudo constatar que el uso del NR-31 es deficiente, incluso con el alcance y detalle provisto en su texto. En el estudio se constató que el entorno laboral rural 
es preocupante, debido a los numerosos riesgos que se presentan en el ejercicio de sus actividades y la falta de respeto por el incumplimiento de la NR-31. Es fundamental que las autoridades gubernamentales, además de fiscalizar el fiel cumplimiento de la norma, realicen labores de sensibilización entre trabajadores y empleadores, con miras a mejorar las condiciones laborales en las zonas rurales. Cobra relevancia la priorización que debe darse a la sensibilización, educación, formación y adecuación de las condiciones laborales, como medida de prevención de accidentes y enfermedades en el sector agrário.

Palabras clave: Seguridad del trabajo; Campo; NR-31.

\section{Introduction}

In 2019, agribusiness had (and still plays) a prominent role in the development of Brazil. In that year, the sum of goods and services generated by the rural environment earned around R 1.55 trillion, which corresponded to $21.4 \%$ of the Brazilian GDP. In addition, the sector employs practically 1 in every 3 Brazilian workers (CNA, 2020).

However, this sector, which employs several employees, brings with it the concern with work accidents and occupational diseases, which can occur in different environments and affect any worker, bringing consequences that can lead to temporary interruption of work activities and even death (Maia \& Rodrigues, 2012).

In rural areas, there are numerous risks that workers face when performing their activity; or in the management of chemical products (such as pesticides) as well as in the operation of heavy vehicles (such as tractors on uneven terrain); and, to aggravate the problem, in many cases, employees carry out their activities in an erroneous manner, such as not using Personal Protective Equipment (PPE) and disobeying (or not knowing) the NR (s) regulatory standards, especially the standard that aims to take care of the safety of rural workers, which is NR-31 (Seifert \& Santiago, 2009). For this reason, statistically, rural workers are twice more involved in work accidents than urban workers (Briques \& Patrocínio, 2016).

Therefore, the present work was developed with the objective of pointing out the difficulties found that prevent the faithful fulfillment of Regulatory Norm $\mathrm{n}^{\circ} 31$ - Safety and Health at Work in Agriculture, Livestock, Forestry, Forestry and Aquaculture in rural areas.

\section{Materials and Methods}

\subsection{Risk for the rural worker}

Generally, accidents that occur in rural areas are caused by failure to observe two factors, namely: unsafe conditions and unsafe acts, which can occur together or separately (Silva \& Michaloski, 2017).

Also, according to the same authors, unsafe conditions are unfavorable circumstances in the work environment that, for some reason, put the worker's physical integrity at risk (Brito, 2021). Unsafe acts, on the other hand, are caused by a human factor, that is, the work that is performed improperly by the worker, causing him to assume responsibility for the accident (Bevilaqua, 2020).

The three actions that make up unsafe acts are: negligence, malpractice, and recklessness (Lima, 2021). Negligence is when the worker does not comply with the safety standards in force in the workplace; this is generally the cause of most workplace accidents (Montagner, 2021). Malpractice is characterized when the cause of the accident stems from the fact that the employee performs an activity that he or she does not have technical capacity (Machado, 2017). Finally, recklessness is defined when the worker performs a service without paying due attention to the procedures adopted, despite knowing them (Silva \& Michaloski, 2017).

In Brazil, there is no exact data that can specify the number of accidents that occur during the working day (Morin, 2018). However, some estimates assume that around 3 million accidents with workers occur annually. In rural areas, the situation worsens, as people work on their own and rarely record the occurrence of accidents (Marques \& Silva, 2003).

The Department of Labor of the Ministry of Economy, which performs the function of the former Ministry of Labor, 
through Ordinance $N^{0}$ 25, of December 29, 1994, classifies the main occupational hazards as: chemical risk, biological risk, physical risk, mechanical risk, and ergonomic risk (Dias, 2006). In Table 1, the risk factors, and possible damages that they can cause to rural workers are shown.

Table 1. Main risk factors and possible work-related harm or damage to the worker's health.

\begin{tabular}{|c|c|c|c|}
\hline Risk type & Risk factor & Work status & Health harm or damage \\
\hline \multirow{6}{*}{ Physical } & Heat & $\begin{array}{l}\text { Working outdoors, under solar radiation, next to } \\
\text { machines, engines, and boilers; difficulties in water } \\
\text { replacement due to access to water or cultural barriers }\end{array}$ & $\begin{array}{c}\text { Thermal stress, cramps, heat syncope, heat } \\
\text { fatigue and heat stroke }\end{array}$ \\
\hline & $\begin{array}{l}\text { Cold, wind and } \\
\text { rain }\end{array}$ & Outdoor work & Upper airway disorders, colds \\
\hline & Lightning & Open field work during storms & Electric shock \\
\hline & Vibration & $\begin{array}{l}\text { Operation of agricultural machines, tractors, electric } \\
\text { saw, producing whole body vibration or localized } \\
\text { vibration, particularly in hands and arms }\end{array}$ & $\begin{array}{l}\text { Low back pain, peripheral vascular disease, } \\
\text { musculoskeletal disease }\end{array}$ \\
\hline & Noise & $\begin{array}{l}\text { Working with machines: tractors, combines and other } \\
\text { agricultural machines }\end{array}$ & $\begin{array}{c}\text { Hearing loss and other extra-auditory effects } \\
\text { resulting from exposure to noise, such as sleep } \\
\text { disturbance, nervousness, gastrointestinal } \\
\text { disorders }\end{array}$ \\
\hline & Solar radiation & $\begin{array}{c}\text { Open field work for long periods, with exposure to } \\
\text { ultraviolet radiation }\end{array}$ & Skin cancer \\
\hline Chemical & $\begin{array}{l}\text { Chemical agents } \\
\text { miscellaneous, } \\
\text { fertilizers and } \\
\text { fertilizers, } \\
\text { pesticides, in the } \\
\text { form of gases, } \\
\text { dust and mists }\end{array}$ & $\begin{array}{l}\text { - Application of fertilizers and fertilizers (nitrates, } \\
\text { phosphates and potassium-NPK salts, sulfur compounds, } \\
\text { magnesium, manganese, iron, zinc, copper, among } \\
\text { others); } \\
\text { - Preparation of mixtures and application of pesticides } \\
\text { (anticides, larvicides, herbicides, acaricides, ticks, } \\
\text { molluscicides, raticides, repellents, fungicides, } \\
\text { herbicides, defoliants, defoliants, desiccants, anti-spring } \\
\text { agents, sterilants, bactericides, plant growth regulators); } \\
\text { - Treatment and storage of grains; } \\
\text { - The storage and handling of animal excrement can } \\
\text { expose the worker to hydrogen sulphide and ammonia; } \\
\text { - Shrimp farming }\end{array}$ & $\begin{array}{c}\text { - Contact dermatitis; } \\
\text { - Rhinitis and conjunctivitis; } \\
\text { - Intoxications by pesticides; } \\
\text { - obstructive respiratory disease; } \\
\text { - Bronchitis, occupational asthma; } \\
\text { - restrictive lung disease; } \\
\text { - Interstitial lung disease with fibrosis; } \\
\text { - Cancer; } \\
\text { - Neurological disease; } \\
\text { - Changes in mood and behavior; } \\
\text { - Endocrine changes; } \\
\text { - Reproductive changes }\end{array}$ \\
\hline Biological & $\begin{array}{l}\text { Bacteria, viruses, } \\
\text { fungi, } \\
\text { mites } \\
\text { animal bites } \\
\text { venomous. }\end{array}$ & $\begin{array}{c}\text { - Preparation and handling of animal feed; moldy hay, } \\
\text { decaying feed, sugar cane fibres, mushroom preparation, } \\
\text { feedlot poultry treatment; } \\
\text { - Animal management; } \\
\text { - Soil preparation work, pasture cleaning, weeding and } \\
\text { harvesting }\end{array}$ & $\begin{array}{c}\text { - Rhinitis and conjunctivitis; } \\
\text { - Obstructive respiratory diseases, occupational } \\
\text { asthma; } \\
\text { - Snake and spider bites; } \\
\text { - Q fever, brucellosis, psittacosis, tularemia, } \\
\text { bovine and avian tuberculosis, leptospirosis, } \\
\text { histoplasmosis, rabies; } \\
\text { - Burns by caterpillars; } \\
\text { - Snake and spider bites }\end{array}$ \\
\hline \multirow{2}{*}{ Mechanic } & $\begin{array}{l}\text { Sharp, heavy } \\
\text { hand tools, } \\
\text { pointed }\end{array}$ & $\begin{array}{l}\text { - Use of machete, sickle, axe, saw, hoe, hammer; } \\
\text { - Inappropriate tools, adapted and in poor condition }\end{array}$ & $\begin{array}{l}\text { - Acute injuries: work accidents with cuts and } \\
\text { crushing; } \\
\text { - Chronic lesions: hyperkeratosis }\end{array}$ \\
\hline & $\begin{array}{l}\text { Machines and } \\
\text { implements } \\
\text { agricultural }\end{array}$ & $\begin{array}{l}\text { Poor worker posture, repetitive movements and } \\
\text { machinery vibration }\end{array}$ & $\begin{array}{l}\text { - DORT; } \\
\text { - Accidents at work and low back pain }\end{array}$ \\
\hline Ergonomic & $\begin{array}{c}\text {-Work } \\
\text { relationships; } \\
\text { - Precariousness; } \\
\text { - Seasonality of } \\
\text { production that } \\
\text { imposes an } \\
\text { overload of work }\end{array}$ & $\begin{array}{c}\text { - Work far from the worker's home, precarious } \\
\text { accommodation, poor sanitation and comfort. } \\
\text { - Inadequate food, long working hours, under heavy time } \\
\text { pressure. } \\
\text { - Precarious and rigidly hierarchical work relationships. }\end{array}$ & $\begin{array}{l}\text { - Mental suffering; } \\
\text { - Sleep and mood disorders; } \\
\text { - Fatigue } \\
\text { - DORT }\end{array}$ \\
\hline
\end{tabular}


In addition to the factors presented in the table above, it is noted that the rural worker is exposed to other secondary factors, which can contribute to potentiate the risks described above (Petarli, 2021). These are: psychosomatic problems, addictions (in alcohol and cigarettes), low education, low income, and devaluation of work; that is, linked to the economic, social, and environmental situation in which they find themselves (Peres et al., 2005).

\subsection{Regulatory standards (NRs)}

Aiming to standardize, inspect and establish guidelines on mandatory procedures relating to safety and occupational medicine, the Ministry of Labor and Employment (MTE), in July 1978, was responsible for preparing 28 Regulatory Norms. Currently, there are 36 standards that address the subject. Thus, through Ordinance No. 3.214, June 8, 1978 (still in force), of the extinct MTE, the Regulatory Standards were approved, rewording Chapter V, Title II, of the Consolidation of Labor Laws (CLT), which are mandatory for all Brazilian companies (Brasil, 1978).

These standards are developed and amended through specific tripartite committees made up of government officials, contractors, and contractors (Ribeiro, 2021).

In this work, the focus was NR 31, which determines the safety guidelines for rural workers.

\subsection{NR-31 - Regulatory standard for safety and health at work in agriculture, livestock forestry, forestry, and aquaculture}

Initially, rural labor safety was regulated by Law No. 5.889, of June 5, 1973; whose Rural Regulatory Norms (NRRs) were approved by Ordinance $N^{0} 3,067$ of April 12, 1988. However, this ordinance was revoked by Ordinance GM No 86 , of March 3, 2005, which concentrated all rural labor regulation in a single specific Regulatory Norm, NR-31 (FUNIP, 2019).

This NR establishes the precepts to be observed in the organization and in the work environment, in order to make the planning and development of activities in agriculture, livestock, forestry, forestry and aquaculture compatible with the safety and health and environment of work (Souza, 2008).

Even with a specific guideline for rural workers, it is still possible to see that there are difficulties in implementing this legislation effectively, since it is not complied with in the work environment due to the main and secondary factors mentioned earlier in this work (Quarto, 2021).

\section{Results and Discussion}

\subsection{Challenges for nr-31}

NR-31 provides that the contractor must guarantee ideal working conditions, hygiene, and comfort; assess the risks present in the workplace and implement protection and prevention measures; and instruct and train employees so that they perform their functions safely (Briques \& Patrocínio, 2016). However, it is common to find numerous situations that demonstrate the employer's disregard for the employee, such as: the non-availability of Personal Protective Equipment (PPE) and the non-supervision of its use (and/or correct use) by the employer; the inexistence of sanitary facilities in the workplaces and their quantity, given the number of employees; failure to perform a medical-laboratory examination upon admission; the absence of fresh drinking water in the workplace; the lack of adequate canteens; and finally, the lack of materials and specialized personnel to provide first aid (Souza, 2008).

In addition, in its text, NR-31 presents detailed guidelines regarding the correct use and use of the various types of PPE by workers; as well as those used in collective protection - Collective Protection Equipment (EPCs) (Briques \& Patrocínio, 2016). 
However, it appears that both employers and employees are unaware of the guidelines contained in NR-31, regarding the use of PPE and/or EPC; and sometimes such equipment is not used due to physical discomfort (ergonomic), sometimes caused by its prolonged use (Briques \& Patrocínio, 2016).

The non-use of PPE becomes even more worrying when it comes to activities related to the use of chemical products, such as pesticides, as these products can harm the worker's health; such practice frequently occurs in small rural communities (Silva, 2019).

Also, in relation to the handling of pesticides, it is noteworthy that PPE can be sources of contamination, being a risk to the health of the individual and the community; because, due to lack of training (or deficient training) and/or low education of workers, they sometimes contribute to the neglect of measures related to the conservation, use and disposal of this equipment. Unfortunately, workers end up choosing to perform their work more comfortably than following the protocols provided for in the standard and using PPE(s) with pesticides (Souza, 2008).

Another problem that involves the worker in the field lies in the relationship between the number of workers and the amount of PPE available for certain activities; since, if the worker refuses to perform their tasks due to the absence of equipment, they may be dismissed and replaced by another who will occupy their role (Briques \& Patrocínio, 2016).

\section{Conclusion}

Based on the facts presented above, it is possible to see that the rural work environment is worrying, due to the numerous risks that are present in the exercise of their activities and the disregard for non-compliance with NR-31.

Therefore, it is suggested that in future work the government authorities, in addition to inspecting the faithful compliance with the standard, must carry out a work of awareness of workers and employers, aiming to provide an improvement in working conditions in the rural environment.

Thus, the prioritization that should be given to awareness, education, training, and adequacy of working conditions becomes relevant, as a measure to prevent accidents and diseases in the agricultural sector.

\section{Acknowledgments}

This research was partially financed by the Brazilian Federal Agencies Conselho Nacional de Desenvolvimento Científico e Tecnológico (CNPq), and Coordenação de Aperfeiçoamento de Pessoal de Nível Superior (CAPES), Brazil.

\section{References}

Bevilaqua, M. D., Degasperin, N. G., Godoi, R. F., \& Morschbacher, J. (2020). Implicação à saúde do trabalhador rural devido a exposições e uso de agrotóxicos: perspectivas para a enfermagem. Anuário Pesquisa e Extensão Unoesc, São Miguel do Oeste, 5. https://unoesc.emnuvens.com.br/a peusmo/article/view/24895/14652

Brasil. (1987). Portaria no 3.214, de 8 de junho de 1978. Aprova as Normas Regulamentadoras - NR - do Capítulo V, Título II, da Consolidação das Leis do Trabalho, relativas à Segurança e Medicina do Trabalho. http://www81.dataprev.gov.br/sislex/paginas/63/mte/1978/3214.htm.

Briques, A. D., \& Patrocínio, A. B. (2016). Análise da Dificuldade da Aplicação Efetiva da Norma Regulamentadora 31 do Ministério do Trabalho. Regent: Revista Eletrônica de Gestão, Engenharia e Tecnologia da Faculdade de Tecnologia de Piracicaba, 1 (1), 1-14.

Brito, L. M., Maracajá, P. B., Medeiros, A. C., Feitosa, A. N. A., Dantas, M. C. A. M., \& Fernandes Filho, A. (2021). Intoxicações por agrotóxicos: Impactos causados pela utilização indiscriminada em comunidades rurais. Research, Society and Development, 10 (8), e56710817418-e56710817418 10.33448/rsdv10i8.17418.

CNA. Confederação da Agricultura e Pecuária do Brasil. (2020). Panorama do Agro. 16/11/2020. Online. https://www.cnabrasil.org.br/cna/panorama-do-agro.

Dias, E. C. (2006). Condições de vida, trabalho, saúde e doença dos trabalhadores rurais no Brasil. In: Pinheiro, T. M. M. (org.). Saúde do trabalhador rural Renast. Brasília (DF): Ministério da Saúde, 1-27.

Funip. Faculdade Única de Ipatinga. (2019). Engenharia de Segurança do Trabalho: Legislações e Normas. 11/03/2019. 
Lima, V. A. P., Oliveira, A. F., Alves, D. A., \& Oliveira, J. R. (2021). Segurança e saúde no ambiente de trabalho rural do Alto Jequitinhonha, Minas Gerais. Scientific Electronic Archives, 14 (3), 71-77. 10.36560/14320211243.

Machado, L. M., Beck, C. L. C., Coelho, A. P. F., Weiller, T. H., \& Camponogara, S. (2017). Atuação dos profissionais de saúde da família frente ao trabalhador rural exposto a agrotóxicos. Ciência, Cuidado e Saúde, 16 (3), 1-8. 10.4025/cienccuidsaude.v16i3.37051

Maia, L. R., \& Rodrigues, L. B. (2012). Saúde e segurança no ambiente rural: uma análise das condições de trabalho em um setor de ordenha. Ciência Rural, 42 (6), 1134-1139. 10.1590/S0103-84782012000600030.

Marques, S. M. T., \& Silva, G. P. (2003). Trabalho e acidentes no meio rural do Oeste Catarinense - Santa Catarina, Brasil. Revista Brasileira de Saúde Ocupacional, 28 (107-108), 101-105. 10.1590/S0303-76572003000200009.

Montagner, S. E. D., Colet, C. F., Maldaner, K. L., Silva, J. A. G., Fell, A. P. W., Carbonera, R., \& Stumm, E. M. F. (2021). Caracterização de indivíduos com câncer, residentes no meio rural, práticas no uso de agrotóxicos e níveis de acetilcolinesterase eritrocitárias. Research, Society and Development, 10 (5), e54310515072. 10.33448/rsd-v10i5.15072.

Morin, P. V., \& Stumm, E. M. F. (2018). Transtornos mentais comuns em agricultores, relação com agrotóxicos, sintomas físicos e doenças preexistentes. Psico, 49 (2), 196-205. 10.15448/1980-8623.2018.2.26814

Peres, F., Rozemberg, B., \& Lucca, S. R. (2005). Percepção de riscos no trabalho rural em uma região agrícola do Estado do Rio de Janeiro, Brasil: agrotóxicos, saúde e ambiente. Cadernos de Saúde Pública, 21 (6), 1836-1844. 10.1590/S0102-311X2005000600033.

Petarli, G. B., Salaroli, L. B., \& Cattafesta, M. (2021). Saúde, Trabalho e Ambiente: Um Olhar Interprofissional para a Saúde de Populações Rurais. Curitiba: Editora Appris. 329p.

Quarto, L. C., Cardoso, D. M., \& Souza, C. F. O. B. A. (2021). Contexto brasileiro das pesquisas científicas acerca da saúde ocupacional do trabalhador rural: um levantamento na base de dados Scopus Elsevier. Brazilian Journal of Policy and Development, 3 (2), 26-39. 10.52367/BRJPD.2675-102X.2021.3.2.26-39.

Ribeiro, J. O. C., Arruda, V. M., Carvalhido, A. C. M., \& Ribeiro, C. D. L. (2021). A agroecologia como realização da sustentabilidade no meio ambiente do trabalho rural. Cap.3, p. 39-46. In: Silveira, J. L. (org.). Gestão ambiental: Práticas, Sustentabilidade e Inovação. Formiga: Editora MultiAtual, 51p.

Seifert, A. L., \& Santiago, D. C. (2009). Formação dos profissionais das áreas de ciências agrárias em segurança do trabalho rural. Ciência e Agrotecnologia, 33 (4), 131-1138. 10.1590/S1413-70542009000400026.

Silva, R. C. A. (2019). A Saúde do Trabalhador Rural e a Segurança do Trabalho: Um Estudo de Caso. Trabalho de conclusão de curso (Tecnologia em Gestão Ambiental). Instituto Federal de Educação, Ciência e Tecnologia do Piauí, Campus Corrente. 22p.

Silva, S. S., \& Michaloski, A. O. (2017). A Norma Regulamentadora nº10 e a sua Aplicação em Instalações Elétricas e seus Entornos. Revista TécnicoCientífica do Crea, 5 (6), 1-8.

Souza, M. C. M. (2008). O Meio Ambiente do Trabalho: A Questão do Trabalho Rural nas Usinas da Região da Alta Sorocabana e Alta Paulista e o Cumprimento da Norma Regulamentadora 31, Referente à Segurança e Saúde no Trabalho, do Ministério do Trabalho e Emprego. Revista Tópos, 2 (2), 92 112. 